\title{
Breeding objectives for three silvicultural regimes of radiata pine
}

\author{
Luis A. Apiolaza and Dorian J. Garrick
}

\begin{abstract}
A generic vertically integrated firm, comprising a production forest, a sawmill, and a pulp mill was modelled under three silvicultural regimes: direct to pulp, intermediate (includes production thinning), and intensive (includes production thinnings and pruning). The harvest age traits included in the breeding objective were total volume ( $\mathrm{m}^{3} / \mathrm{ha}$ ) and average wood density $\left(\mathrm{kg} / \mathrm{m}^{3}\right)$. Economic values for each trait were calculated as the difference in discounted profit for a unit marginal increase of volume or density, and expressed as relative weights to facilitate comparisons between the objectives. The methodology was applied to a Chilean case study using representative economic and production circumstances. The breeding objectives so derived were $1 \mathrm{vol}+2.4 \mathrm{den}$ for pulp, $1 \mathrm{vol}+1.1 \mathrm{den}$ for intermediate, and $1 \mathrm{vol}+1.2 \mathrm{den}$ for the intensive regime, where vol and den are the breeding values for volume and density, respectively. The firm was profitable under all regimes. Genetic correlations between the objectives for each regime were higher than 0.9 , indicating that a single breeding strategy with objective $1 \mathrm{vol}+1.5 \mathrm{den}$ could be adopted, with almost no loss of genetic gain relative to selecting for a particular silvicultural regime.
\end{abstract}

Résumé : Les auteurs ont simulé une compagnie générique intégrée verticalement et comprenant une forêt commerciale, une scierie et une usine de pâte selon trois régimes sylvicoles : le bois directement acheminé à l'usine de pâte, un régime intermédiaire (comprenant une éclaircie commerciale) et un régime intensif (comprenant des éclaircies commerciales et de l'élagage). Les caractères à l'âge de la récolte qui étaient compris dans l'objectif d'amélioration étaient le volume total $\left(\mathrm{m}^{3} / \mathrm{ha}\right)$ et la densité moyenne du bois $\left(\mathrm{kg} / \mathrm{m}^{3}\right)$. La valeur économique de chaque caractère a été calculée comme la différence entre le profit obtenu pour une augmentation marginale unitaire du volume ou de la densité. Ces valeurs ont été exprimées sur une base relative afin de faciliter les comparaisons entre les objectifs. La méthode a été appliquée à une étude de cas au Chili avec des conditions représentatives, tant au niveau de l'économie que de la production. Les objectifs d'amélioration ainsi obtenus étaient de $1 \mathrm{vol}+2,4 \mathrm{den}$ pour la pâte, 1 vol + 1,1den pour le régime intermédiaire et $1 \mathrm{vol}+1,2$ den pour le régime intensif, où vol et den sont les objectifs d'amélioration pour le volume et la densité, respectivement. La compagnie enregistrait des profits sous tous les régimes. Les corrélations génétiques entre les objectifs pour chacun des régimes étaient supérieures à 0,9 , indiquant ainsi qu'une stratégie unique d'amélioration avec un objectif de $1 \mathrm{vol}+1,5 \mathrm{den}$ serait envisageable, avec presque aucune perte de gain génétique relativement à la sélection en fonction d'un régime sylvicole particulier.

[Traduit par la Rédaction]

\section{Introduction}

The forest industry is a complex system where plantations are grown, harvested, and then processed to produce many different end products. Assuming that forest companies work in a competitive market, where the participants are interested in profit, it is possible to assume the industry is driven by profit maximization. Profit, defined as the difference between discounted incomes and costs, is a complex function depending on many production and economic variables. An in-

Received June 22, 2000. Accepted December 12, 2000.

Published on the NRC Research Press Web site on

April 13, 2001.

L.A. Apiolaza. ${ }^{1}$ Cooperative Research Centre for Sustainable Production Forestry and School of Plant Science, University of Tasmania, G.P.O. Box 252-55, Hobart, Tasmania 7001, Australia (e-mail: luis.apiolaza@utas.edu.au).

D.J. Garrick. Institute of Veterinary, Animal and Biomedical Sciences, Massey University, Private Bag 11222, Palmerston North, New Zealand (e-mail: d.garrick@massey.ac.nz).

${ }^{1}$ Corresponding author. crease in profit can be achieved through increasing incomes (either higher quantity or quality of products), reducing costs, or various combinations including both components. A better quality product should attract a price premium, while an incremental increase in volume of production at the same costs reduces average costs per unit.

Tree breeding is one of the tools utilized by the industry to increase profit. Hazel (1943) formalized the concept of breeding objective $(H)$ or aggregate economic genotype as a linear combination of additive genetic values of two or more traits weighted by their relative economic values:

$$
H=v_{1} a_{1}+v_{2} a_{2}+\ldots+v_{n} a_{n}=\mathbf{v}^{\prime} \mathbf{a}
$$

where $\mathbf{v}^{\prime}=\left[v_{1}, v_{2}, \ldots, v_{n}\right]$ is the vector of relative economic values and $\mathbf{a}^{\prime}=\left[a_{1}, a_{2}, \ldots, a_{n}\right]$ is the vector of additive genetic values. An economic weight represents the benefit of one unit improvement of the trait without altering the other traits present in the objective (Hazel 1943). Sometimes a distinction is made between absolute benefit (economic value) and relative benefit (economic weight) of improving a trait. The selection criteria in a breeding program are not necessarily the same as the traits in the objective, although their 
choice is dictated by the traits in the objective (Barlow 1987; Ponzoni and Newman 1989). These criteria are normally combined in a selection index $(I)$ with weights that maximize the correlation between $H$ and $I$ :

$$
I=c_{1} y_{1}+c_{2} y_{2}+\ldots+c_{m} y_{m}=\mathbf{c}^{\prime} \mathbf{y}
$$

where $\mathbf{c}^{\prime}=\left[c_{1}, c_{2}, \ldots, c_{m}\right]$ is the vector of index weights calculated using genetic and economic information and $\mathbf{y}^{\prime}=\left[y_{1}\right.$, $\left.y_{2}, \ldots, y_{m}\right]$ is the selection criteria or vector of assessments (adjusted for fixed effects). If $\mathbf{G}$ is the $m \times n$ additive genetic covariance matrix among the $m$ criteria in the index and the $n$ traits in the objective, and $\mathbf{P}$ is the $m \times m$ phenotypic covariance matrix among the criteria in the index, $\mathbf{c}=\mathbf{P}^{-1} \mathbf{G v}$. This index is optimal when genetic effects are completely additive and the economic weights are linear functions of their genetic value (Gibson and Kennedy 1990). Thus, knowledge of the breeding objective (traits and their economic weights) is a necessary condition to optimize selection in a breeding program incorporating multiple traits.

A good starting point to define a breeding objective is asking "what do we want to improve?" (Ponzoni and Newman 1989). Usually it is possible to define the breeding objective as profit maximization. The ideal breeding objective should comprise all traits which influence returns and costs, regardless of whether they can be measured or changed by selection (Gjedrem 1972; James 1982; Ponzoni 1982; Barlow 1987; Ponzoni and Newman 1989). However, in practice the objective often only includes traits with reliable information and under genetic control (Borralho et al. 1993). Although in theory developing the breeding objective is the first step necessary to establish a breeding programme, this step has usually been postponed in tree breeding for several reasons: (i) complexity of the forest processing industry; (ii) heterogeneity of wood properties, which make it difficult to ascertain relationships between wood properties and final quantity and quality of products; and (iii) a perception of breeding objectives research being of low priority.

While there have been previous attempts to value the contribution of tree breeding to industry profit (e.g., Löfgren 1988), Borralho et al. (1993) were the first to present a formal derivation of breeding objectives in forestry, using pulp production of Eucalyptus globulus Labill. in Portugal as an example. Greaves and Borralho (1996) and Greaves et al. (1997a) extended the model with a more complete description of the pulping system of eucalypts in Australia, while Chambers et al. (1997) presented a breeding objective for thermomechanical pulping and newsprint production of radiata pine (Pinus radiata D. Don). Lowe et al. (1999) applied the general methodology of Borralho et al. (1993) to kraft and mechanical pulping of loblolly pine (Pinus taeda L.) in United States. All these models considered a cost-minimization perspective. Shelbourne (1997) emphasized the need to breed for added value to the end-product traits of radiata pine. Shelbourne et al. (1997) presented a comprehensive list of potentially important traits for different end products of radiata pine. These traits might change both quantity and quality of end products or alter costs or incomes from industrial processes. Greaves (1999) developed the first objective considering sawn timber and accounting for quality of the product, expressed by structural grade.
Fig. 1. Schematic diagram of a generic vertically integrated industry.

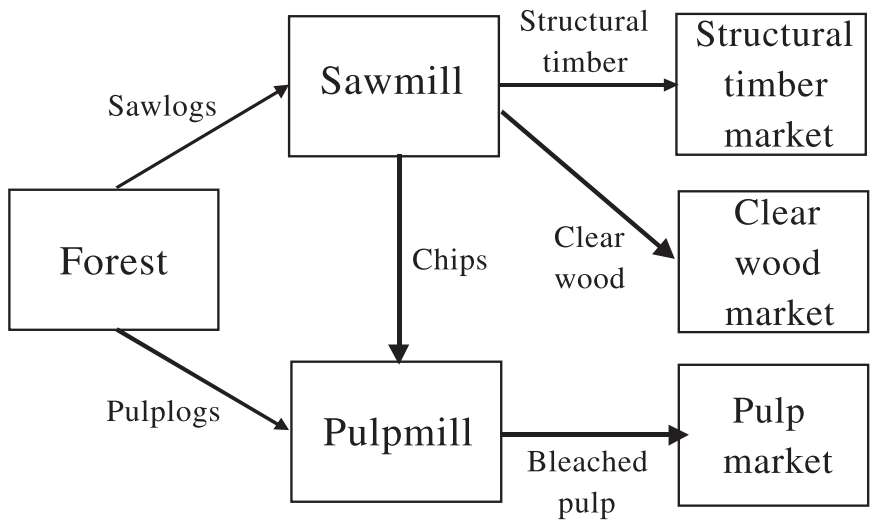

The definition of a breeding objective requires study of the economic system that makes use of the trees available for breeding. The forest industry comprises several tiers (e.g., production forests, sawmills, pulp mills), and different products may have different requirements. Thus, the economic values are specific to the industry structure, and the nature of costs and incomes (e.g., see Groen (1989) in an animal breeding context). At this stage it is necessary to define who benefits from the breeding program, because depending on the answer the objectives may differ (see Amer and Fox (1992) for a discussion). It is also necessary to define what are the restrictions (e.g., capital), if any, faced by the investors to define the profit criterion used in the breeding objective. With no restrictions, net present value per hectare may be an appropriate criterion; however, in the presence of capital constraints maximizing the ratio of profit per unit of cost invested per hectare (profitability index) may be more appropriate (Allen 1991).

Radiata pine is the main plantation species in Chile, generating more than $90 \%$ of the income from the forestry sector. Breeding of radiata pine in Chile started in the early 1980s, with the establishment of a university-industry cooperative program to serve the needs of a diversity of industrial processes. The objective of the research reported in this paper is to develop simple breeding objectives to maximize profit of a generic vertically integrated industry, comprising a production forest, a sawmill, and a pulp mill. Hence, the objective explicitly considers the value of end products rather than assessing production values from a fixed return for raw materials. Three silvicultural regimes appropriate to sites of varying quality (pulp, intermediate, and intensive) are considered, to represent part of the diversity of cost-income structure of the Chilean situation. Finally, we determine the compatibility of the breeding objectives for simultaneous application in a breeding program.

\section{Methods}

\section{Traits in the objective}

Two traits are considered in the breeding objective: harvestable volume $\left(\mathrm{m}^{3} / \mathrm{ha}\right)$ and average wood density $\left(\mathrm{kg} / \mathrm{m}^{3}\right)$, both expressed at rotation age (years). The choice of traits is based on their influence on profit, already demonstrated in previous studies (e.g., 
Table 1. Description of the silvicultural regimes.

\begin{tabular}{llll}
\hline & \multicolumn{3}{l}{ Silvicultural regime } \\
\cline { 2 - 4 } Descriptor & Pulp & Intermediate & Intensive \\
\hline Site index (m) & 22 & 25 & 30 \\
Rotation (years) & 18 & 22 & 26 \\
Initial stocking (stems/ha) & 1600 & 1400 & 1100 \\
Thinning to waste at age 5 (residual stems/ha) & 800 & 700 & 800 \\
Production thinning at age 12 (residual stems/ha) & - & 400 & 400 \\
Prunings (ages) & - & - & $5,6,7$ \\
\hline
\end{tabular}

${ }^{a}$ Average height of tallest 100 trees per hectare at age 20 years.

Borralho et al. 1993; Greaves 1999), the possibility of constructing sensible relationships between forest and end products (using either the objective traits or variables derived from them) and on the intent of keeping the breeding objective as simple as possible. A given volume per hectare was described as a function of basal area $\left(\mathrm{m}^{2} / \mathrm{ha}\right)$, top height $(\mathrm{m})$, and stocking rate (trees/ha), accounting for individual variation of the trees that populate 1 ha of forest.

\section{Production system}

A vertically integrated production system was modelled, which included tree growing, harvesting, and processing in a sawmill and pulp mill (Fig. 1) and considered three silvicultural regimes according to site quality expressed as site index (SI). Low-quality sites $(\mathrm{SI}=22)$ were managed with a pulp regime, medium-quality sites $(\mathrm{SI}=25)$ with an intermediate regime, and high-quality sites $(\mathrm{SI}=30)$ were under an intensive silvicultural regime. Table 1 provides a description of the characteristics of each regime.

\section{Growth model}

A stand model based on a system of differential equations as described by García $(1984,1994,1999)$ was used to model the production forest tier and provided expected values for basal area, top height, and stocking rate. Average wood density was modelled using a quadratic model described by Tian et al. (1995). Random sampling procedures were used to simulate the individual stems that contribute to the population of stems. Diameters of individual trees were generated from stand parameters using a Weibull distribution, the parameters of which were obtained using a simplified method of moments (García 1981). Total tree height was obtained using an exponential height-diameter function, and wood density was derived using a normal distribution. Each silvicultural regime was simulated 100 times to explore the variability of results produced when generating individual trees using stochastic distributions.

\section{Log generation}

Trees were "cut" using three common log specifications based on length and small-end diameter $(2.44 \mathrm{~m}, 10 \mathrm{~cm} ; 3.60 \mathrm{~m}, 15 \mathrm{~cm}$; and $4.00 \mathrm{~m}, 20 \mathrm{~cm}$, respectively). Each stem was represented by three parameters: diameter at breast height, total height, and wood density at breast height. The stem is compared with the largest log specification, if the remaining length and small-end diameter, calculated through a taper function, exceeds the log specifications the tree is cut. Otherwise, the model tries to fit the second largest log specification and so on, until the remainder of the tree is too small for any specification and is considered waste. This algorithm is a simplified version of that suggested by Goulding and Shirley (1979). An average wood density was assigned to each log using a parabolic function of height and wood density at breast height based on the model by Tian et al. (1995).

\section{Log processing}

Logs of $2.44 \mathrm{~m}$ are used only for pulping. The mass of pulp for each $\log \left(\mathrm{TON}_{\text {pulp }}\right)$ was calculated as

$$
\mathrm{TON}_{\text {pulp }}=\mathrm{VOL}_{\log } \times \mathrm{DEN}_{\log } \times \mathrm{PY}_{\log }
$$

where volume of $\log$ calculation $\left(\mathrm{VOL}_{\log }\right.$ in $\mathrm{m}^{3}$ ) is obtained from the large-end diameter $\left(\mathrm{LED}_{\log }\right.$ in $\left.\mathrm{cm}\right)$, small-end diameter $\left(\mathrm{SED}_{\log }\right.$ in $\mathrm{cm}$ ), and length $\left(\mathrm{LEN}_{\log }\right.$ in $\mathrm{m}$ ) of the $\log$ and pulp yield (PY $\mathrm{Pog}_{\mathrm{log}}$ as proportion) using a function of basic wood density $\left(\mathrm{DEN}_{\mathrm{log}}\right)$ approximated from data in Evans et al. (1999):

$$
\mathrm{VOL}_{\log }=\frac{\pi \times \mathrm{LEN}_{\log } \times\left(\mathrm{LED}_{\log }^{2}+\mathrm{LED}_{\log } \times \mathrm{SED}_{\log }+\mathrm{SED}_{\log }^{2}\right)}{120000}
$$

$$
\mathrm{PY}_{\log }=0.37462+0.00024 \times \mathrm{DEN}_{\log }
$$

The same function of yield is used for chips produced by the sawmill. Logs larger than $2.44 \mathrm{~m}$ are used in the sawmill, where the volume of timber is estimated as

$$
\mathrm{VOL}_{\text {timber }}=\frac{\mathrm{LEN}_{\log } \times \mathrm{SED}_{\log }^{2}}{20000}
$$

In light framing construction, one of the main uses of radiata pine, stiffness (expressed as modulus of elasticity) is the most important property of the timber. Stiffness is closely related to wood density (Cown 1992). Modulus of elasticity of timber $\left(\mathrm{MOE}_{\text {timber }}\right.$ in GPa) was estimated as a function of basic density (Bier 1985) and subsequently the grade of structural timber was obtained as a function of modulus of elasticity:

$$
\mathrm{MOE}_{\text {timber }}=-3.66+0.027 \times \mathrm{DEN}_{\log }
$$

For logs $3.6 \mathrm{~m}$ long the volume of structural timber was

$$
\mathrm{VOL}_{\text {struc }}=\mathrm{VOL}_{\text {timber }}
$$

In the case of $4 \mathrm{~m}$ long logs the proportion of timber that is clear wood is calculated using a second-degree polynomial function based on data from Table 15 of Cown (1992), assuming a 20$\mathrm{cm}$ diameter over stump (DOS): 
Table 2. Cost structure for the silvicultural regimes.

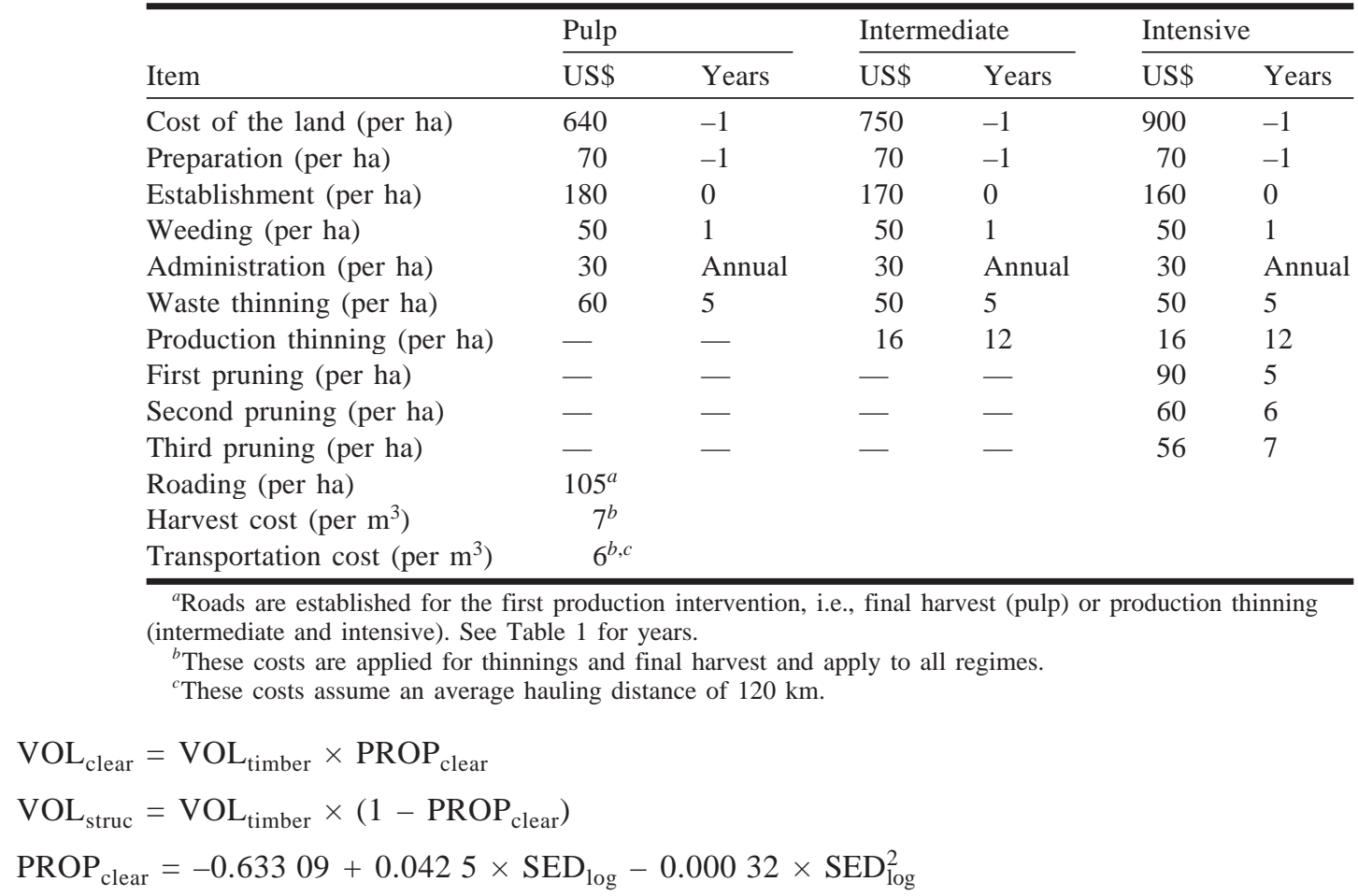

Ninety percent of the difference between volume of the log and volume of timber is considered to be chips, while the residual is considered to be losses in the process (e.g., sawdust):

$$
\mathrm{VOL}_{\text {chips }}=\left(\mathrm{VOL}_{\log }-\mathrm{VOL}_{\text {timber }}\right) \times 0.9
$$

\section{Cost-income structure}

Discounted income $(I)$ of the production system was derived from selling timber (structural and (or) clear) and chemical pulp:

$$
I=\sum_{k=-1}^{r}\left(\mathrm{INCOME}_{\text {struc }_{k}}+\mathrm{INCOME}_{\text {clear }_{k}}+\mathrm{INCOME}_{\text {pulp }_{k}}\right) \lambda^{k}
$$

where $r$ is rotation age, $\lambda=1 /(1+\alpha)$, and $\alpha$ is the discount rate (cost of capital) expressed as proportion.

$$
\begin{aligned}
& \mathrm{INCOME}_{\text {struc }_{k}}=\mathrm{VOL}_{\text {struc }_{k}} \times \mathrm{PRICE}_{\text {struc }} \\
& \mathrm{INCOME}_{\text {clear }_{k}}=\mathrm{VOL}_{\text {clear }_{k}} \times \mathrm{PRICE}_{\text {clear }} \\
& \mathrm{INCOME}_{\text {pulp }_{k}}=\mathrm{TON}_{\text {pulp }_{k}} \times \mathrm{PRICE}_{\text {pulp }}
\end{aligned}
$$

Discounted cost $(C)$ includes contributions from growing the forest, delivering the wood (roading, harvesting, and transportation), and processing the logs. We assume there is no payment for raw materials between the processing and forest growing tiers (i.e., no transfer cost). Growth and delivery costs are summarized in Table 2. Hence:

$$
C=\sum_{k=-1}^{r}\left(\operatorname{COST}_{\text {growing }_{k}}+\operatorname{COST}_{\text {delivery }_{k}}+\operatorname{COST}_{\text {processing }_{k}}\right) \lambda^{k}
$$

where

$$
\operatorname{COST}_{\text {growing }_{k}}=\operatorname{COST}_{\text {estab }_{k}}+\operatorname{COST}_{\text {admin }_{k}}+\operatorname{COST}_{\text {interv }_{k}}
$$

$\operatorname{COST}_{\text {estab }_{k}}$ considers cost of the land, preparation, planting, and weeding; $\operatorname{COST}_{\text {admin }_{k}}$ are the annual administration costs; and COST interv $_{k}$ includes the costs of thinning to waste and prunings.

$$
\operatorname{COST}_{\text {delivery }_{k}}=\operatorname{COST}_{\text {roading }_{k}}+\left(\mathrm{VOL}_{\text {pulplogs }_{k}}+\mathrm{VOL}_{\text {sawlogs }_{k}}\right) \times\left(\mathrm{COST}_{\text {harvest }}+\mathrm{COST}_{\text {transport }}\right)
$$

where $\operatorname{COST}_{\text {roading }_{k}}>0$ only for the first production intervention.

$$
\mathrm{COST}_{\text {processing }_{k}}=\left(\mathrm{VOL}_{\text {pulplogs }_{k}}+\mathrm{VOL}_{\text {chips }_{k}}\right) \times \mathrm{COST}_{\text {pulping }}+\mathrm{VOL}_{\text {sawlogs }_{k}} \times \mathrm{COST}_{\text {sawing }}
$$

where pulplogs include all 2.44-m logs, and sawlogs include all 3.6-m and 4-m logs. The costs of processing a cubic metre of green wood in the sawmill and pulp mill (COST $_{\text {sawing }}$ and $\mathrm{COST}_{\text {pulping, }}$, respectively) were considered constant. 
Table 3. Average wood and end-product flow per hectare for the production system under three silvicultural regimes.

\begin{tabular}{|c|c|c|c|c|c|}
\hline \multirow[b]{2}{*}{ Products } & \multirow{2}{*}{$\frac{\text { Pulp }}{\text { Age } 18}$} & \multicolumn{2}{|c|}{ Intermediate } & \multicolumn{2}{|c|}{ Intensive } \\
\hline & & Age 12 & Age 22 & Age 12 & Age 26 \\
\hline Pulplogs $\left(m^{3}\right)$ & 332.0 & 42.3 & 72.3 & 119.3 & 65.5 \\
\hline Sawlogs $\left(\mathrm{m}^{3}\right)$ & - & - & 336.9 & - & 609.2 \\
\hline Structural $\left(\mathrm{m}^{3}\right)^{a}$ & - & - & 184.2 & - & 219.7 \\
\hline Clear wood $\left(\mathrm{m}^{3}\right)^{a}$ & - & - & - & - & 123.1 \\
\hline Chips $\left(\mathrm{m}^{3}\right)$ & - & - & 137.5 & - & 239.8 \\
\hline Bleached pulp (t) ${ }^{a}$ & 63.3 & 7.4 & 39.3 & 20.8 & 66.5 \\
\hline
\end{tabular}

Discounted profit $(P)$ or net present value is the difference between the discounted incomes and costs:

$$
P=I-C
$$

\section{Economic values}

Economics values were obtained from an incremental economic evaluation, where the value of a marginal increase of a trait was the difference between the actual cash flow and the base cash flow, i.e., with no increase on the trait (Allen 1991):

$$
\mathrm{EVALUE}=\frac{P_{\Delta}-P_{\text {base }}}{\mathrm{TRAIT}_{\Delta}-\mathrm{TRAIT}_{\text {base }}}
$$

To simulate the increase in stand volume and average wood density rotations were extended between 1 and 2 years (depending on the silvicultural regime) to obtain stand parameters reflecting an increase of $10 \%$ on the traits. In this way, changes to basal area, stocking, and top height are accounted for. A $10 \%$ change in the traits was used, because smaller changes are more difficult to reliably quantify in the model.

The prices of the end products were structural timber, US $\$ 175 / \mathrm{m}^{3}$; clear wood, US $\$ 350 / \mathrm{m}^{3}$; and bleached pulp, US $\$ 430 / \mathrm{t}$. The sum of financial and operational costs (excluding cost of logs) for processing $1 \mathrm{~m}^{3}$ of green wood were US\$35 in the pulp mill and US\$45 in the sawmill. Discounted profit was calculated using a $10 \%(\alpha=$ 0.1 ) discount rate.

\section{Response to selection}

The response per generation in the objective $H\left(\Delta G_{H}\right)$ when selecting on index $I$ is (Van Vleck et al. 1987):

$$
\Delta G_{H}=i r_{I H} \sigma_{H}
$$

where $i$ is the selection intensity, $r_{I H}$ is the correlation between the index and the objective (accuracy of prediction), and $\sigma_{H}$ is the standard deviation of the objective. Correlated response in objective $H_{1}\left(\Delta c G_{H_{1}}\right)$ to selection for objective $H_{2}$ is calculated as

$$
\Delta c G_{H_{1}}=b_{H_{1} H_{2}} \Delta G_{H_{2}}
$$

where $b_{H_{1} H_{2}}$ is the regression of $H_{1}$ on $H_{2}$. If both objectives have equal variance, this expression reduces to (see Appendix):

$$
\Delta c G_{H_{1}}=r_{H_{1} H_{2}} \Delta G_{H_{2}}
$$

where $r_{H_{1} H_{2}}$ is the genetic correlation between objectives $H_{1}$ and $\mathrm{H}_{2}$. If the variances of the objectives are not equal the correlated response is only proportional to $r_{\mathrm{H}_{1} \mathrm{H}_{2}}$.

The following "consensus" parameters are assumed: heritability for volume is 0.2 , heritability for wood density is 0.6 , and the genetic and phenotypic correlations between the traits are -0.3 and -0.1 , respectively (e.g., see Burdon and Low 1992; Shelbourne 1997 and references cited therein). Thus, additive genetic (G) and phenotypic $(\mathbf{P})$ covariance matrices are

$$
\mathbf{G}=\left[\begin{array}{rr}
350 & -141 \\
-141 & 630
\end{array}\right]
$$

and

$$
\mathbf{P}=\left[\begin{array}{ll}
1750 & -135.55 \\
-135.55 & 1050
\end{array}\right]
$$

It is necessary to point out that genetic parameters involving wood properties have often been estimated with small sample sizes and (or) inappropriate sampling schemes (see Apiolaza et al. 1999), and therefore, they are not completely reliable.

\section{Results and discussion}

\section{Wood flow and cost-income structure}

Table 3 presents the average wood and end-product flow for 100 simulations of the base scenario for the silvicultural regimes. Total volume of logs (including production thinnings and final harvest) were $332.0,451.5$, and $794.0 \mathrm{~m}^{3} /$ ha for pulp, intermediate, and intensive regimes, respectively. Wood densities at harvest age were 405,404 , and $409 \mathrm{~kg} / \mathrm{m}^{3}$, respectively, reflecting differences in site quality (measured as site index) and rotation age.

The recovery rate for the sawmill (expressed as the ratio (structural volume + clear volume)/ sawlogs volume) is 0.55 for intermediate and 0.56 for intensive regimes. Green wood requirements to produce a tonne of bleached pulp ((pulplogs + chips)/bleached pulp) were, on average, 5.2, 5.4, and $4.9 \mathrm{~m}^{3}$ for pulp, intermediate, and intensive regimes, respectively, showing the effect of age and site quality on basic wood density and, consequently, on pulp yield.

For the base scenario, as a proportion of total discounted costs, growing costs range between 24 (intensive) and 32\% (pulp), delivery costs between 16 (intermediate) and 19\% (pulp), and processing costs (pulping + sawing) between 49 (pulp) and 59\% (intensive) (Table 4). In general, better sites and silviculture result in a shift in costs, as a percentage, towards the processing end. Concerning incomes, both the intermediate and intensive regimes were characterized by $60 \%$ in the sawmill and the remainder in the pulp mill (Table 4).

Increasing volume or density within a silvicultural regime did not noticeably change (more than 1\%) the percentage cost structure reported in Table 4 , but the percentages of income coming from pulp mill and sawmill were altered. In 
Table 4. Discounted cost and income structure expressed as percentage of total discounted costs and incomes for the base scenarios.

\begin{tabular}{|c|c|c|c|}
\hline \multirow[b]{2}{*}{ Item } & \multicolumn{3}{|c|}{ Silvicultural regime } \\
\hline & Pulp & Intermediate & Intensive \\
\hline \multicolumn{4}{|l|}{ Costs } \\
\hline Growing & 32 & 27 & 24 \\
\hline Delivery $^{a}$ & 19 & 16 & 17 \\
\hline Pulping & 49 & 25 & 30 \\
\hline Sawing & - & 32 & 29 \\
\hline \multicolumn{4}{|l|}{ Incomes } \\
\hline Pulping $^{b}$ & 100 & 44 & 42 \\
\hline Sawing & - & 56 & 58 \\
\hline
\end{tabular}

${ }^{a}$ Includes production thinnings, final harvest, roading, and transportation.

${ }^{b}$ Includes processing pulplogs and chips from sawlogs.

the intermediate regime sawing income starts at $56 \%$ for the base case and moves to $58 \%$ for the $10 \%$ volume increase $\left(\mathrm{VOL}_{\Delta}\right)$ and to $53 \%$ for the $10 \%$ density increase $\left(\mathrm{DEN}_{\Delta}\right)$. The percentages for the intensive regime move from $58 \%$ (base) to $61 \%\left(\mathrm{VOL}_{\Delta}\right)$ and to $55 \%\left(\mathrm{DEN}_{\Delta}\right)$.

The base models for all regimes were profitable (Table 5), with discounted profit per hectare (including forest, pulp mill and sawmill) ranging from US\$659.06 (pulp) to US\$4289.70 (intensive). The increase of harvested volume (due to higher site index and longer rotation) as well as the introduction of high value products (clear wood) justifies the difference in profit between pulp and more intensive regimes. Table 5 shows the change of profit by increasing $\sim 10 \%$ final harvest volume $\left(34,33\right.$, and $\left.71 \mathrm{~m}^{3} / \mathrm{ha}\right)$ and wood density $\left(40.5,40.4\right.$, and $\left.40.9 \mathrm{~kg} / \mathrm{m}^{3}\right)$ of the pulp, intermediate, and intensive regimes, respectively. Percentage profit increase due to volume ranges between 18 (intermediate) and $32 \%$ (pulp), while the increase caused by density ranges between 14 (intensive) and 92\% (pulp).

Economic values for each trait-regime combination ( $V$, extra profit per unit increase) are presented in Table 5. The largest economic effect of increasing volume is in the intensive regime (11.94), reflecting the associated log size increase, improving sawmill recovery, and quantity of structural and clear wood. Increasing density is more valuable in the pulp regime (14.90), because it directly improves the efficiency of pulp production. Thus, the breeding objectives were as follows: $6.26 \mathrm{vol}+14.90 \mathrm{den}$ for pulp, $8.28 \mathrm{vol}+9.42 \mathrm{den}$ for intermediate, and $11.94 \mathrm{vol}+14.70 \mathrm{den}$ for the intensive regime, where vol and den are the breeding values for volume and density, respectively. Standard errors for the estimates of economic values, obtained from 100 simulations, are small and show more variability for volume than for density. The similarities of economic values were more clearly interpreted when using relative weights. Relative economic weights for volume and density were $1: 2.4,1: 1.1$, and $1: 1.2$ for pulp, intermediate, and intensive regimes, respectively.

\section{Multiple objectives}

The existence of several production conditions (e.g., silvicultural regimes) and economic circumstances (e.g., future end-product prices) creates sets of economic values for the traits under breeding. As a result, breeders face the decision of keeping a single breeding population with a unique objective (either the objective for a specific condition or an average objective) or splitting the population and breeding for different objectives (Del Bosque González and Kinghorn 1990; Howarth et al. 1997; Howarth and Goddard 1998). The convenience of each option depends, among other factors, on the correlation between the breeding values.

Correlations between breeding objectives are very high, with values of 0.94 for pulp-intermediate, 0.96 for pulpintensive, and 0.99 for intermediate-intensive regimes. The variances of the breeding objectives were 127278.9 , 57904.1 , and 136537.9 for the pulp, intermediate, and intensive regimes, respectively. Because the variances are different it is considered that correlated response is only proportional to the correlation between objectives. The objectives for intermediate and intensive regimes are almost identical in the sense of ranking, although the economic values are different such the investment decisions may vary with regimes. Although splitting the breeding population in specialist "breeds" would maximize individual response for each objective, this would simultaneously increase the breeding work and costs and reduce overall selection intensity. As an illustration, considering 600 plus trees with 30 progeny each, selection of top 200 for the next generation implies a selection intensity $(i)$ of 2.634 (200 of 18000$)$ for a single population, while the intensity is 2.231 (200 of 6000) when the population is split in three specialist "breeds" (Falconer and Mackay 1996). The economic values for an "average" breeding objective (see Appendix) are 8.83 and $13.01\left(\left(\mathbf{v}_{1}+\mathbf{v}_{2}+\mathbf{v}_{3}\right) / 3\right)$, i.e., the economic weights are 1:1.5. Direct responses to selection using specialist "breeds" are US\$589, US\$349, and US\$544 for pulp, intermediate, and intensive regimes, respectively, while direct response to selection on the average objective is US\$579. Correlated response (see Appendix) on breeding objective for pulp, intermediate, and intensive regimes to selection based on an average index will result in $1.10,0.75$ and 1.15 units, respectively, of aggregate genotype per unit of response on the average objective. Considering these results and assuming other conditions identical, i.e., same selection criteria and generation interval, the firm is better off keeping a single breeding population.

\section{Final remarks}

The profit in the production system may be utilized to determine the most appropriate payment system for raw materials, as well as to calculate the profit of the different tiers of the firm. There is a large degree of uncertainty in the costincome structure of the generic firm, especially concerning future end-product prices. One option to tackle this problem is to change the discount rate used in the economic evaluation. Alternative approaches are to include the error probability distribution of the parameters estimated with uncertainty in the estimation of selection indices (Amer and Hofer 1994), or to run alternative realistic scenarios. Another problem is that part of the economic value of a trait can result from changes in the operation of the firm; thus, operations of the firm must be optimized accordingly to reflect those changes (Amer et al. 1994). 
Table 5. Discounted cash flow for the base, $10 \%$ volume increase $\left(\mathrm{VOL}_{\Delta}\right)$, and $10 \%$ density increase cases $\left(\mathrm{DEN}_{\Delta}\right)$, where $P$ is discounted profit and $V$ is the economic value for a unit increase of volume $\left(1 \mathrm{~m}^{3}\right)$ and wood density $\left(1 \mathrm{~kg} / \mathrm{m}^{3}\right)$.

\begin{tabular}{|c|c|c|c|c|c|c|}
\hline \multirow[b]{2}{*}{ Model } & \multicolumn{2}{|l|}{ Pulp } & \multicolumn{2}{|c|}{ Intermediate } & \multicolumn{2}{|l|}{ Intensive } \\
\hline & $P$ & $V$ & $P$ & $V$ & $P$ & $V$ \\
\hline Base & 659.06 & - & 1549.37 & - & 4289.70 & - \\
\hline $\mathrm{VOL}_{\Delta}$ & 871.98 & $6.26(0.09)$ & 1822.57 & $8.28(0.12)$ & 5137.58 & $11.94(0.15)$ \\
\hline $\mathrm{DEN}_{\Delta}$ & 1262.34 & $14.90(0.06)$ & 1929.94 & $9.42(0.01)$ & 4890.91 & $14.70(0.22)$ \\
\hline
\end{tabular}

Note: Standard errors for $V$ obtained from 100 simulations are shown in parentheses.

The breeding objectives modelled in this paper considered only two traits, currently included in the breeding strategy. There are several other traits with potential economic effect on the production system (e.g., Shelbourne et al. 1997). For example, in sawmills, recovery rate is affected by log sweep and taper (Brown and Miller 1975; Kellogg and Warren 1984). Mechanical performance of lumber (measured as stiffness and strength) is related to wood density, internode index and branch index (Cown 1992). Dimensional stability of planks depends on spiral grain. Lignin and cellulose content affect the yield of kraft pulp production, while the quality of pulp and paper is related to tracheid dimensions (Kibblewhite et al. 1996). Moreover, there are other end products and industrial processes (e.g., paper, fiberboards, veneers, carbon sequestration) that should be implemented in the model. Biological traits for some of these products have been listed elsewhere (Shelbourne et al. 1997). Once additional processing information is available to the breeder it is feasible to include additional traits in the objectives.

The calculation of economic values presented in this paper relies on the linearity of profit increase with changes on volume and density. This is not necessarily the case, as shown by Greaves et al. (1997b) in eucalypts. Some traits are inherently nonlinear, like those based on threshold values (e.g., spiral grain or grades for structural wood) where improvement of the trait has value only when reaching a given threshold (e.g., Colleau and Le Bihan-Duval 1995). There is a considerable body of research concerning selection on nonlinear breeding objectives (e.g., Goddard 1983; Itoh and Yamada 1988; Burdon 1990) with varying conclusions concerning the importance of nonlinearity. The relevance of nonlinearity to practical selection and breeding programs is an issue that will need to be explored in detail.

\section{Acknowledgments}

This project was developed while L.A.A. was a Ph.D. student at the Institute of Veterinary, Animal and Biomedical Sciences, Massey University, New Zealand. He was funded by New Zealand Official Development Assistance and New Zealand Forest Research Institute scholarships. Many thanks to Ramy Alzamora (Instituto de Manejo Forestal, Universidad Austral de Chile), Verónica Alvarez, and Ignacio Cerda (Departamento de Estudios Económicos, INFOR, Chile) for providing information regarding Chilean silvicultural regimes, prices, and costs structures. Oscar García (University of Northern British Columbia) and Bob Shula (New Zealand Forest Research Institute) provided much help to understand growth models. The help of Bruce Greaves and Paul Cham- bers (University of Tasmania) providing unpublished material and valuable comments is much appreciated.

\section{References}

Allen, D.H. 1991. Economic evaluation of projects-a guide. Stephen Austin \& Sons, Hertford, U.K.

Amer, P.R., and Fox, G.C. 1992. Estimation of economic weights in genetic improvement using neoclassical production theory: an alternative to rescaling. Anim. Prod. 54: 341-350.

Amer, P.R., and Hofer, A. 1994. Optimum bias in selection index parameters estimated with uncertainty. J. Anim. Breed. Genet. 111: 89-101.

Amer, P.R., Fox, G.C., and Smith, C. 1994. Economic weights from profit equations: appraising their accuracy in the long run. Anim. Prod. 58: 11-18.

Apiolaza, L.A., Burdon, R.D., and Garrick, D.J. 1999. Effect of univariate subsampling on the efficiency of bivariate parameter estimation and selection using half-sib progeny tests. For. Genet. 6: 79-87.

Barlow, R. 1987. An introduction to breeding objectives for livestock. In Australian Association of Animal Breeding and Genetics. Proceedings of the Sixth Conference, 9-11 February, Perth, Australia. pp. 162-169.

Bier, H. 1985. Bending properties of structural timber from a 28year-old stand of New Zealand Pinus radiata. N.Z. J. For. Sci. 15: 233-250.

Borralho, N.M.G., Cotterill, P.P., and Kanowski, P.J. 1993. Breeding objectives for pulp production of Eucalyptus globulus under different industrial costs structures. Can. J. For. Res. 23: 648-656.

Brown, A.G., and Miller, R.G. 1975. Effect of sweep on sawn recovery from radiata pine logs. Aust. For. Res. 7: 29-39.

Burdon, R.D. 1990. Implications of non-linear economic weights for breeding. Theor. Appl. Genet. 79: 65-71.

Burdon, R.D., and Low, C.B. 1992. Genetic survey of Pinus radiata. 6: Wood properties: variation, heritabilities, and interrelationships with other traits. N.Z. J. For. Sci. 22: 228-245.

Chambers, P.G.S., Borralho, N.M.G., Banham, P.W., and Cox, R.E. 1997. Impact of wood selection traits on a thermo-mechanical pulping system using Pinus radiata to produce newsprint. In IUFRO '97 Genetics of Radiata Pine. Proceedings of NZFRIIUFRO Conference 1-4 December and Workshop 5 December, Rotorua, New Zealand. Edited by R.D. Burdon and J.M. Moore. New Zealand Forest Research Institute, Rotorua. For. Res. Inst. Bull. 203. pp. 155-159.

Colleau, J.J., and Le Bihan-Duval, E. 1995. A simulation study of selection methods to improve mastitis resistance of dairy cows. J. Dairy Sci. 78: 659-671.

Cown, D.J. 1992. New Zealand radiata pine and Douglas fir. Suitability for processing. New Zealand Forest Research Institute, Rotorua. For. Res. Inst. Bull. s168. 
Del Bosque González, A.S., and Kinghorn, B.P. 1990. Implications of different selection objectives within open nucleus breeding schemes. In Australian Association of Animal Breeding and Genetics. Proceedings of the 8th Conference, 5-9 February 1990, Hamilton and Palmerston North, New Zealand. pp. 95-102.

Evans, R., Kibblewhite, R.P., and Lausberg, M. 1999. Relationships between wood and pulp properties of twenty-five 13 year old radiata pine trees. APPITA J. 52: 132-139.

Falconer, D.S., and Mackay, T.F.C. 1996. Introduction to quantitative genetics. Longman, Essex, U.K.

García, O. 1981. Note: Simplified method-of-moments estimation for the Weibull distribution. N.Z. J. For. Sci. 11: 304-306.

García, O. 1984. New class of growth models for even-aged stands: Pinus radiata in Golden Downs forest. N.Z. J. For. Sci. 14: 6588.

García, O. 1994. The state-space approach in growth modelling. Can. J. For. Res. 24: 1894-1903.

García, O. 1999. Height growth of Pinus radiata in New Zealand. N.Z. J. For. Sci. 29: 131-145.

Gibson, J.P., and Kennedy, B.W. 1990. The use of constrained selection indexes in breeding for economic merit. Theor. Appl. Genet. 80: 801-805.

Gjedrem, T. 1972. A study of the definition of the aggregate genotype in a selection index. Acta Agric. Scand. 22: 11-16.

Goddard, M.E. 1983. Selection indices for non-linear profit functions. Theor. Appl. Genet. 64: 339-344.

Goulding, C.J., and Shirley, J.W. 1979. A method to predict the yield of $\log$ assortments for long term planning. In Mensuration for management planning of exotic forest plantations. Compiled by D.A. Elliott. N.Z. Forest Service, Rotorua. For. Res. Inst. Symp. 20. pp. 301-314.

Greaves, B.L. 1999. The value of tree improvement: a case study in radiata pine grown for structural sawn timber and liner-board. In Connection Between Silviculture and Wood Quality through modelling approaches and Simulation Software. Proceedings of IUFRO Workshop, 5-12 December 1999, La Londe-Les-Maures, France. Edited by G. Nepveu. IUFRO, Vienna. pp. 448-459.

Greaves, B.L., and Borralho, N.M.G. 1996. The influence of basic density and pulp yield on the cost of eucalypt kraft pulping: a theoretical model for tree breeding. APPITA J. 49: 423-426.

Greaves, B.L., Borralho, N.M.G., and Raymond, C.A. 1997a. Breeding objective for plantation eucalypts grown for production of kraft pulp. For. Sci. 43: 465-475.

Greaves, B.L., Borralho, N.M.G., and Raymond, C.A. 1997b. Assumptions underlying the use of economic weights-are they valid in breeding for eucalypt pulp? For. Genet. 4: 35-42.

Groen, A.F. 1989. Economic values in cattle breeding. I. Influences of production circumstances in situations without output limitations. Livest. Prod. Sci. 22: 1-16.

Hazel, L.N. 1943. The genetic basis for constructing selection indexes. Genetics, 28: 476-490.

Howarth, J.M., and Goddard, M.E. 1998. Maximising response and profit under multiple objective selection. In Proceedings of the 6th World Congress of Genetics Applied to Livestock Production, 11-16 January 1998, Armidale, Australia. Vol. 25. pp. 359362.

Howarth, J.M., Goddard, M.E., and Kinghorn, B.P. 1997. Breeding strategies for targeting different breeding objectives. In Proceedings of the 12th Conference of the Association for the Advancement of Animal Breeding and Genetics, 6-10 April 1997, Dubbo, Australia. Part 1. pp. 99-102.

Itoh, Y., and Yamada, Y. 1988. Linear selection indices for nonlinear profit functions. Theor. App. Genet. 75: 553-560.
James, J.W. 1982. Economic aspects of developing breeding objectives: general considerations. In Future developments in the genetic improvement of animals. Edited by J.S.F. Barker, K. Hammond, and A.E. McClintock. Academic Press, Marrickville, Australia. pp. 107-117.

Kellogg, R.M., and Warren, W.G. 1984. Evaluating western hemlock stem characteristics in terms of lumber value. Wood Fiber Sci. 16: 583-597.

Kibblewhite, R.P., Evans, R., and Riddell, M.J.C. 1996. Handsheet property prediction from kraft fibre and wood tracheid properties in eleven radiata pine clones. In Proceedings of the 50th APPITA Annual General Conference, Auckland, New Zealand.

Löfgren, K.G. 1988. On the economic value of genetic progress in forestry. For. Sci. 34: 708-723.

Lowe, W.J., Byram, T.D., and Bridgwater, F.E. 1999. Selecting loblolly pine parents for seed orchards to minimize the cost of producing pulp. For. Sci. 45: 213-216.

Ponzoni, R.W. 1982. Breeding objectives in sheep breeding programmes. In Proceedings of the 2nd World Congress of Genetics Applied to Livestock Production, Madrid, Spain. Vol X. pp. 619-634.

Ponzoni, R.W., and Newman, S. 1989. Developing breeding objectives for Australian beef cattle production. Anim. Prod. 49: 3547.

Searle, S.R. 1982. Matrix algebra useful for statistics. John Wiley \& Sons, New York.

Shelbourne, C.J.A. 1997. Genetics of adding value to the endproducts of radiata pine. In IUFRO '97 Genetics of Radiata Pine. Proceedings of NZFRI-IUFRO Conference 1-4 December and Workshop 5 December 1997, Rotorua, New Zealand. Edited by R.D. Burdon and J.M. Moore. New Zealand Forest Research Institute, Rotorua. For. Res. Inst. Bull. 203. pp. 129-141.

Shelbourne, C.J.A., Apiolaza, L.A., Jayawickrama, K.J.S., and Sorensson, C.T. 1997. Developing breeding objectives for radiata pine in New Zealand. In IUFRO ' 97 Genetics of Radiata Pine.” Proceedings of NZFRI-IUFRO Conference 1-4 December and Workshop 5 December 1997, Rotorua, New Zealand. Edited by R.D. Burdon and J.M. Moore. New Zealand Forest Research Institute, Rotorua. For. Res. Inst. Bull. 203. pp. 160-168.

Tian, X., Cown, D.J., and McConchie, D.L. 1995. Modelling of Pinus radiata wood properties. Part 2: basic density. N.Z. J. For. Sci. 25: 214-230.

Van Vleck, L.D., Pollak, E.J., and Oltenacu, E.A.B. 1987. Genetics for the animal sciences. W.H. Freeman \& Co., New York.

\section{Appendix}

\section{Some results on breeding objectives}

\section{Correlation between breeding objectives}

The correlation between two objectives $H_{1}$ and $H_{2}\left(r_{H_{1} H_{2}}\right)$ is calculated as

$$
r_{H_{1} H_{2}}=\frac{\operatorname{Cov}\left(H_{1}, H_{2}\right)}{\sqrt{\operatorname{Var}\left(H_{1}\right) \operatorname{Var}\left(H_{2}\right)}}
$$

Variance and covariances of linear expressions are quadratic forms represented as a covariance matrix pre- and post-multiplied by a vector (Searle 1982, p. 73). Hence:

$$
r_{H_{1} H_{2}}=\mathbf{v}_{1}^{\prime} \mathbf{G} \mathbf{v}_{2}\left(\mathbf{v}_{1}^{\prime} \mathbf{G} \mathbf{v}_{1}\right)^{-0.5}\left(\mathbf{v}_{2}^{\prime} \mathbf{G v}_{2}\right)^{-0.5}
$$




\section{Correlated response}

Correlated response in breeding objective $1\left(H_{1}\right)$ when selection is based on an index derived to maximize response on breeding objective $2\left(\mathrm{H}_{2}\right)$ can be calculated using the regression of $H_{1}$ on $H_{2}\left(b_{H_{1} H_{2}}\right)$ :

$$
\begin{aligned}
\Delta c G_{H_{1}} & =b_{H_{1} H_{2}} \Delta G_{H_{2}} \\
& =\frac{\operatorname{Cov}\left(H_{1}, H_{2}\right)}{\operatorname{Var}\left(H_{2}\right)} \Delta G_{H_{2}} \\
& =\mathbf{v}_{1}^{\prime} \mathbf{G v}_{2}\left(\mathbf{v}_{2}^{\prime} \mathbf{G v}_{2}\right)^{-1} \Delta G_{H_{2}}
\end{aligned}
$$

Assuming that $\operatorname{Var}\left(H_{1}\right)=\operatorname{Var}\left(H_{2}\right)$, correlated response can be calculated as

$$
\begin{aligned}
\Delta c G_{H_{1}} & =\frac{\operatorname{Cov}\left(H_{1}, H_{2}\right)}{\operatorname{Var}\left(H_{2}\right)} \Delta G_{H_{2}} \\
& =\frac{\operatorname{Cov}\left(H_{1}, H_{2}\right)}{\sqrt{\operatorname{Var}\left(H_{1}\right) \operatorname{Var}\left(H_{2}\right)}} \frac{\sqrt{\operatorname{Var}\left(H_{1}\right)}}{\sqrt{\operatorname{Var}\left(H_{2}\right)}} \Delta G_{H_{2}} \\
& =r_{H_{1} H_{2}} \Delta G_{H_{2}}
\end{aligned}
$$

which shows the relationship of response to the correlation between the objectives.

\section{Average breeding objective}

For each production condition or economic circumstance $i$, there is a breeding objective $H_{i}=\mathbf{v}_{i}^{\prime} \mathbf{a}$ and selection index coefficients $\mathbf{c}_{i}=\mathbf{P}^{-1} \mathbf{G} \mathbf{v}_{i}$, with predicted genetic gain $\Delta G_{i}$. However, it might be possible to have only one generic breeding program, producing material for all sets of production and economic circumstances. The generic breeding objective is $H_{\mathrm{g}}=\mathbf{v}_{\mathrm{g}}^{\prime}$ a and selection index coefficients $\mathbf{c}_{\mathrm{g}}=$ $\mathbf{P}^{-1} \mathbf{G v}_{\mathrm{g}}$, with predicted genetic gain $\Delta G_{\mathrm{g}}$.

Considering $t$ different breeding programs total gain using specialist breeding objectives is given by

$$
T \Delta G=w_{1} \Delta G_{1}+w_{2} \Delta G_{2}+\ldots+w_{t} \Delta G_{t}
$$

where $w_{i}$ is a weight that includes the relative economic importance of the process and (or) the plausibility of the economic circumstance. On the other hand, the total gain for using a generic breeding program is given by

$$
T \Delta G_{\mathrm{g}}=w_{1} \Delta c G_{1}+w_{2} \Delta c G_{2}+\ldots+w_{t} \Delta c G_{t}
$$

where $\Delta c G_{i}$ is the correlated response of breeding objective $i$ when selecting for a generic breeding objective. Correlated response is calculated as

$$
\begin{aligned}
\Delta c G_{i} & =i \mathbf{c}_{\mathrm{g}}^{\prime} \mathbf{G} \mathbf{v}_{i}\left(\mathbf{c}_{\mathrm{g}}^{\prime} \mathbf{P} \mathbf{c}_{\mathrm{g}}\right)^{-0.5} \\
& =i \mathbf{v}_{\mathrm{g}}^{\prime} \mathbf{G} \mathbf{P}^{-1} \mathbf{G} \mathbf{v}_{i}\left(\mathbf{v}_{\mathrm{g}}^{\prime} \mathbf{G} \mathbf{P}^{-1} \mathbf{G} \mathbf{v}_{\mathrm{g}}\right)^{-0.5}
\end{aligned}
$$

and considering $\mathbf{Q}=\mathbf{G P}^{\mathbf{- 1}} \mathbf{G}$ then

$$
\Delta c G_{i}=i \mathbf{v}_{\mathrm{g}}^{\prime} \mathbf{Q} \mathbf{v}_{i}\left(\mathbf{v}_{\mathrm{g}}^{\prime} \mathbf{Q} \mathbf{v}_{\mathrm{g}}\right)^{-0.5}
$$

The vector $\mathbf{v}_{\mathrm{g}}$ should be calculated to minimize the difference between the total genetic gain produced by a generic breeding program and that obtained using several breeding programs or, the same result, maximize the total gain of the common breeding objective $\left(T \Delta G_{\mathrm{g}}\right)$ :

$$
\max T \Delta G_{\mathrm{g}}=w_{1} \Delta c G_{1}+w_{2} \Delta c G_{2}+\ldots+w_{t} \Delta c G_{t}
$$

or equivalent expressions:

$$
\begin{aligned}
& \max T \Delta G_{\mathrm{g}}=\Sigma\left[w_{i} i \mathbf{v}_{\mathrm{g}}^{\prime} \mathbf{Q} \mathbf{v}_{i}\left(\mathbf{v}_{\mathrm{g}}^{\prime} \mathbf{Q} \mathbf{v}_{\mathrm{g}}\right)^{-0.5}\right] \\
& \max T \Delta G_{\mathrm{g}}=i \mathbf{v}_{\mathrm{g}}^{\prime} \mathbf{Q} \Sigma\left[w_{i} \mathbf{v}_{i}\right]\left(\mathbf{v}_{\mathrm{g}}^{\prime} \mathbf{Q} \mathbf{v}_{\mathrm{g}}\right)^{-0.5}
\end{aligned}
$$

Differentiating $T \Delta G_{\mathrm{g}}$ and setting the system of equations equal to 0 :

$$
\begin{aligned}
& \begin{array}{r}
\frac{\delta \mathrm{T} \Delta \mathrm{G}_{\mathrm{g}}}{\delta \mathbf{v}_{\mathrm{g}}}=i \mathbf{Q} \Sigma\left[w_{i} \mathbf{v}_{i}\right]\left(\mathbf{v}_{\mathrm{g}}^{\prime} \mathbf{Q} \mathbf{v}_{\mathrm{g}}\right)^{-0.5} \\
\quad+i \mathbf{v}_{\mathrm{g}}^{\prime} \mathbf{Q} \Sigma\left[w_{i} \mathbf{v}_{i}\right]^{-0.5}\left(\mathbf{v}_{\mathrm{g}}^{\prime} \mathbf{Q} \mathbf{v}_{\mathrm{g}}\right)^{-1.5} 2 \mathbf{Q} \mathbf{v}_{\mathrm{g}}=0
\end{array} \\
& \begin{array}{r}
i\left[\mathbf{Q} \Sigma\left[w_{i} \mathbf{v}_{i}\right]\left(\mathbf{v}_{\mathrm{g}}^{\prime} \mathbf{Q} \mathbf{v}_{\mathrm{g}}\right)^{-0.5}\right. \\
\left.\quad-\mathbf{v}_{\mathrm{g}}^{\prime} \mathbf{Q} \Sigma\left[w_{i} \mathbf{v}_{i}\right]\left(\mathbf{v}_{\mathrm{g}}^{\prime} \mathbf{Q} \mathbf{v}_{\mathrm{g}}\right)^{-1.5} \mathbf{Q} \mathbf{v}_{\mathrm{g}}\right]=0
\end{array} \\
& \mathbf{Q} \Sigma\left[w_{i} \mathbf{v}_{i}\right]\left(\mathbf{v}_{\mathrm{g}}^{\prime} \mathbf{Q} \mathbf{v}_{\mathrm{g}}\right)^{-0.5}=\mathbf{v}_{\mathrm{g}}^{\prime} \mathbf{Q} \Sigma\left[w_{i} \mathbf{v}_{i}\right]\left(\mathbf{v}_{\mathrm{g}}^{\prime} \mathbf{Q} \mathbf{v}_{\mathrm{g}}\right)^{-1.5} \mathbf{Q} \mathbf{v}_{\mathrm{g}} \\
& \mathbf{Q} \Sigma\left[w_{i} \mathbf{v}_{i}\right]=\mathbf{v}_{\mathrm{g}}^{\prime} \mathbf{Q} \Sigma\left[w_{i} \mathbf{v}_{i}\right] \mathbf{Q} \mathbf{v}_{\mathrm{g}}\left(\mathbf{v}_{\mathrm{g}}^{\prime} \mathbf{Q} \mathbf{v}_{\mathrm{g}}\right)^{-1}
\end{aligned}
$$

but $\mathbf{v}_{\mathrm{g}}^{\prime} \mathbf{Q} \Sigma\left[w_{i} \mathbf{v}_{i}\right]$ and $\left(\mathbf{v}_{\mathrm{g}}^{\prime} \mathbf{Q} \mathbf{v}_{\mathrm{g}}\right)^{-1}$ are scalars; thus, the solutions are proportional to their product $(k)$, and $\mathbf{Q}$ is full rank so $\mathbf{Q}^{-1}$ exists.

$$
\mathbf{v}_{\mathrm{g}}=k \Sigma\left[w_{i} \mathbf{v}_{i}\right]
$$

Therefore, $\mathbf{v}_{\mathrm{g}}$ is proportional to the weighted sum of vectors $\mathbf{v}_{i}$ (e.g., the weighted average). If all production conditions or economic circumstances are equally important, $\mathbf{v}_{\mathrm{g}}$ is equal to the arithmetic mean of the $\mathbf{v}_{i}$. 